OPEN ACCESS

Edited by:

Ala-Eddin Al Moustafa

Qatar University, Qatar

Reviewed by:

Veronica Vella

University of Catania, Italy

Ali Vaziri-Gohar

Case Western Reserve University,

United States

*Correspondence:

Consolato Sergi

Sergi@ualberta.ca

Specialty section:

This article was submitted to Molecular and Cellular Oncology,

a section of the journal

Frontiers in Oncology

Received: 09 January 2020

Accepted: 16 April 2020

Published: 15 May 2020

Citation:

Jin L, Shen F, Weinfeld $M$ and Sergi C (2020) Insulin Growth Factor Binding Protein 7 (IGFBP7)-Related Cancer and IGFBP3 and IGFBP7 Crosstalk

Front. Oncol. 10:727.

doi: 10.3389/fonc.2020.00727

\section{Insulin Growth Factor Binding Protein 7 (IGFBP7)-Related Cancer and IGFBP3 and IGFBP7 Crosstalk}

\author{
Li Jin ${ }^{1}$, Fan Shen ${ }^{2}$, Michael Weinfeld ${ }^{3}$ and Consolato Sergi ${ }^{2,4,5,6 *}$ \\ 1 Department of Laboratory Medicine, Shiyan Taihe Hospital, College of Biomedical Engineering, Hubei University of \\ Medicine, Shiyan, China, ${ }^{2}$ Department of Laboratory Medicine and Pathology, University of Alberta, Edmonton, AB, Canada, \\ ${ }^{3}$ Division of Experimental Oncology, Department of Oncology, Cross Cancer Institute, University of Alberta, Edmonton, AB, \\ Canada, ${ }^{4}$ Department of Orthopedics, Tianyou Hospital, Wuhan University of Science and Technology, Wuhan, China, ${ }^{5}$ Key \\ Laboratory of Fermentation Engineering, National "111" Center for Cellular Regulation and Molecular Pharmaceutics, Hubei \\ University of Technology, Wuhan, China, ${ }^{6}$ Stollery Children's Hospital, University Alberta Hospital, Edmonton, AB, Canada
}

The insulin/insulin-like growth factors (IGFs) have crucial tasks in the growth, differentiation, and proliferation of healthy and pernicious cells. They are involved in coordinated complexes, including receptors, ligands, binding proteins, and proteases. However, the systems can become dysregulated in tumorigenesis. Insulin-like growth factor-binding protein 7 (IGFBP7) is a protein belonging to the IGFBP superfamily (also termed GFBP-related proteins). Numerous studies have provided evidence that IGFBP3 and IGFBP7 are involved in a variety of cancers, including hepatocellular carcinoma (HCC), breast cancer, gastroesophageal cancer, colon cancer, prostate cancer, among many others. Still, very few suggest an interaction between these two molecules. In studying several cancer types in our laboratories, we found that both proteins share some crucial signaling pathways. The objective of this review is to present a comprehensive overview of the relationship between IGFBP7 and cancer, as well as highlighting IGFBP3 crosstalk with IGFBP7 reported in recent studies.

Keywords: cancer, growth factors, insulin, binding proteins, mechanism, cross-talk

\section{INTRODUCTION}

\section{IGF System}

The insulin-like growth factor (IGF) signaling axis portrays an essential and pivotal role in cell growth, differentiation, and metabolic processes within the human body. It plays a central role in the development from gestation, continuing its role during life through the stimulation of cell proliferation and blocking programmed cell death $(1,2)$. The IGF system includes two complex coordinated growth factors (IGF-I and IGF-II), and three receptors (IGF-IR, IGF-IIR, and the insulin receptor, IR), six binding proteins (IGFBP-1 to 6) with high-affinity, a group of IGFBP proteases (kallikreins, cathepsins, and matrix metalloproteinases, MMPs), as well as several IGFBP-related proteins (IGFBP-rP 1 to 10 ) with low affinity $(3,4)$. Binding of IGF-1 and IGF-2 with their respective receptors has resulted in a better understanding of this complex machinery. It directs the activation of (1) Ras-Raf-mitogen-activated protein kinases (MAPK) signaling and (2) phosphatidylinositol-4,5-bisphosphate 3-kinase (PI3K)-AKT, through which the IGF axis controls cellular metabolism, tissue homeostasis, and, ultimately, cell survival $(5,6)$.

Several studies have demonstrated that during tumor progression, the influence of the insulin/IGF system on cancer cell behavior is primarily through the regulation of the 
epithelial-mesenchymal transition (EMT) program to obtain a malignant phenotype (7-10). The insulin/IGF system is likewise involved in cancer cell metabolism, resistance to cancer drugs, and cancer stem cell (CSC) phenotypes $(11,12)$, which emphasize the significance of this system in the monitoring networks of the development and progression of cancer.

\section{IGFBP System}

There is evidence indicating that IGFBPs act as transporters of IGFs, lengthen their half-life, and regulate their access to their receptors. According to the distinct affinities to IGFs, IGFBPs are categorized into two groups-binding proteins (IGFBP1-6) with IGF high-affinity and IGFBP-related proteins (IGFBP-rP1-10) with IGF low-affinity. All the IGFBP genes consist of four exons, except IGFBP3, which contains five exons (including one exon, which is apparently not translated). The biological activity of IGFs not only depends on the interaction with IGFRs but also on the influence of the IGFBP family. In biological fluids, the IGFs are often connected with IGFBPs, being rare $(<1 \%)$ in their free form $(5,13)$. The IGFBPs exist in precursor and mature forms. In terms of molecular structure, IGFBPs are broadly composed of three different domains - conserved $\mathrm{N}$ - and C-terminal domains, and a central domain. The $\mathrm{N}$-terminal domain includes an IGFBP motif (GCGCCXXC) that has a significant function in IGF binding. The C-terminal domain is similarly highly conserved. It too plays a critical role in binding to IGFs. The central domain is often labeled as the "binding domain" in the literature. It is usually subjected to post-translational modifications, such as phosphorylation and glycosylation, to control IGFBP activities $(3,14)$. IGFBP-degrading proteases can also influence IGFBP activities, including several MMPs, primarily MMP-7 and MMP9 (15-17). IGFBPs play critical functions in the activity of ligands via the modulation of their half-life. This modulation is obtained by hindering binding with the receptor or alternatively stimulating signaling activation through controlled release of the ligands $(18,19)$. The evidence also suggests that IGFBPs perform insulin/IGF-independent functions, including in the course of tumor progression (20). There are structural and functional similarities between IGFBP-rPs and IGFBPs, but IGFBP-rPs bind with a lower affinity for IGF-I ( $\sim 100$-fold lower) (21). IGFBPs are considered as holding a high affinity for binding to IGFs. This aspect may be due to the formation of a specific binding pocket in the IGFs, and it has been observed that both the N-terminus and, of course, the C-terminus bind to this crucial high-affinity site (22).

\section{IGFBP3}

Like other IGFBPs, IGFBP3 is secreted by many types of cells. It is the major IGF carrier protein that acts in both IGF-independent and IGF-dependent modes in the bloodstream and is the most abundant circulating IGFBP $(3,23)$. Circulating IGFBP3 can form a ternary complex with IGFs and acid-labile subunit (ALS), a liver-derived growth hormone-regulated glycoprotein $(20,24)$. The ternary complex slows down IGFBP3 dissociation rates and extends the IGFBP3 circulating half-life (25). Among the other IGFBPs, only IGFBP- 5 forms a similar ternary complex. These complexes preserve very high concentrations of IGFs in healthy adults. The IGFBP3 C-terminal domain, not only binds IGF but has additionally been shown to be necessary for communications with the ALS all through the IGFBP3 key region Lys 228Arg 232 (22). IGFBP3 plays a significant role involving IGF binding and modulating the distinct biological activities of the IGFs, such as cellular proliferation, cell differentiation, increasing metabolism, and cell survival by regulating their access to the IGF-I receptor (20, 26-29). The affinity between IGFBP3 and IGF-1 is higher than that of IGF-1 and its receptor so that IGFBP3 can compete with IGF blocking the combination of IGF to their receptors. Consequently, IGFBP3 can inhibit cell proliferation and survival (20). Consistent with this, the loss of IGFBP3 expression and consequent de-repression of IGF1R signaling can result in learned resistance to the well-known EGFR tyrosine kinase inhibitor gefitinib (30). IGFBP3 also has IGFindependent antiproliferative and proapoptotic effects, including its interaction with nuclear hormone receptors such as the retinoid $\mathrm{X}$ receptor $(31,32)$ and the vitamin $\mathrm{D}$ receptor $(33)$, the TGF $\beta /$ SMAD (mothers against decapentaplegic) signaling pathways $(34,35)$, and the upregulation of apoptotic effectors (36). The Smad family comprises receptor-regulated (R-) Smads (Smad 1, 2, 3, 5, and 8), common (Co-) Smad 4, and inhibitory (I-) Smads 6 and 7 (37). In the Smad family, Smad 2 and Smad 3 are strongly activated in renal fibrosis in diabetic nephropathy (37).

The deactivation of several proteases regulates the IGFdependent and IGF-independent activity of IGFBP3. According to the tissue type, IGFBP3 specific proteases seem to change. For example, in the quiescent epidermis, MMP-19 is a major IGFBP3 degrading MMP (38), while matrix metalloproteinase-7 seems to degrade IGFBP3 in tumor tissues, enabling IGF bioavailability. Precise data of co-incubation of the IGF-I/IGFBP3 complex with MMP-7 highlighted that such an experiment restores IGFI-mediated IGF-IR phosphorylation and, at the same time, activates AKT in cancer cell lines. This data is outstanding because it indicates that MMP-7 proteolysis of IGFBP3 performs a critical function in synchronizing IGF-I bioavailability, thereby ultimately promoting cell survival (15).

\section{IGFBP7}

IGFBP7 was the first component of IGFBP-related proteins to be discovered. Furthermore, it has been designated as insulin-like growth factor-binding protein-related protein-1 (IGFBP-rp1). This molecule has triggered an enormous interest in cell biology, because it is a secreted protein of a family of low-affinity IGFBPs termed IGFBP-rp1-10 $(22,39)$. It was initially named IGFBP7 because of its capability to attach IGFs through the N-terminal domain (40). IGFBP7 has been cloned from numerous kinds of cellular systems. Thus, it has acquired a variety of differing nomenclature, such as mac25, prostacyclin-stimulating factor (PSF), tumor adhesion factor (TAF), and angiomodulin (AGM). The IGFBP7 gene has been mapped to chromosome 4q12. At the $\mathrm{N}$-terminus of the IGFBP7 molecule, there is an IGFBP motif (GCGCCXXC) in a domain including 12 conserved amino acids (cysteines). The C-terminus of IGFBP7 differs substantially from the other IGFBPs because it lacks the conserved cysteines and in fact has only one cysteine (41). Also, while it has a 100 -fold 


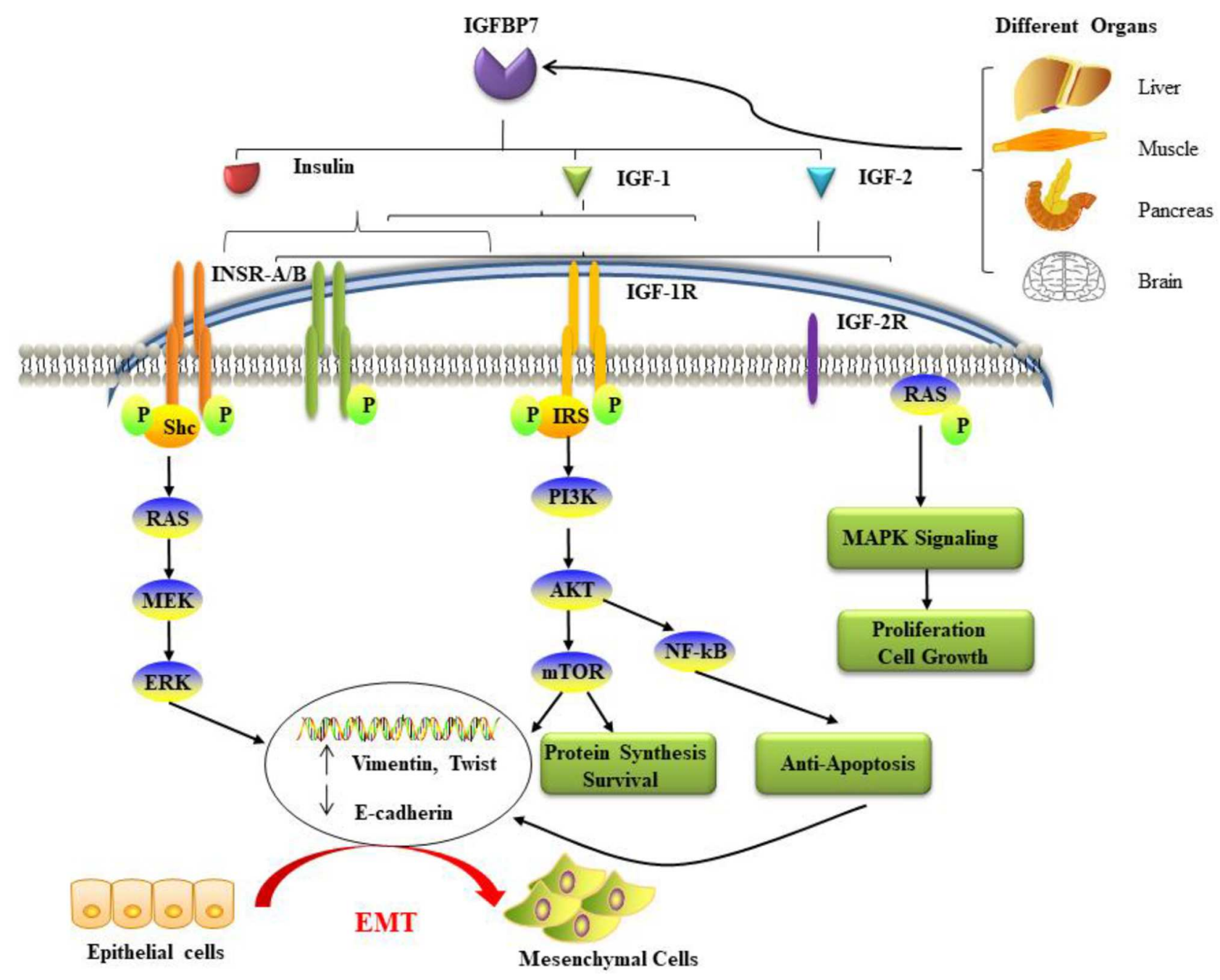

FIGURE 1 | The potential mechanisms and pathways associated with IGFBP7 and cancer. IGFBP7 is expressed at both the protein and mRNA levels in most normal tissues, including the brain, liver, pancreas, and skeletal muscle, and is discharged into circulation. Insulin, IGF-1, and IGF-2 can bind to insulin receptors (INSR-A and INSR-B), IGF-2R has binding affinity only for IGF-2. Ligand activation of IGF-1R results in intrinsic tyrosine kinase phosphorylation. Also, it broadly activates (a crescent is placed backward with "backward" effect in the schema) three main (signaling) pathways: IRS-PI3K-AKT-mTOR signaling, Ras-MEK-ERK pathways, and Ras-MAPK signaling. The first two major pathways induce epithelial cells to lose their cell-cell adhesion and acquire the cellular identity of the mesenchymal phenotype. Loss of epithelial markers such as the cell adhesion molecule E-cadherin and the gain of Vimentin and other mesenchymal markers are considered hallmarks in the initiation and execution of EMT. Activation of the three pathways induces many different effects such as protein synthesis, proliferation, anti-apoptosis, cell survival, and growth. EMT: epithelial-mesenchymal transition; IGF: insulin-like growth factor; IGFBP7: IGF binding protein 7; IGF-1R: IGF-1 receptor; IGF-2R: IGF-2 receptor; INSR: insulin receptor; IRS: insulin receptor substrate; MAPK: mitogen-activated protein kinase; PI3K: phosphatidylinositol-4,5-bisphosphate 3-kinase.

lower affinity for IGF-1 than the other IGFBPs, in contrast to the other family members it binds strongly to insulin, and essentially inhibits the phosphorylation of the insulin receptor $(40,42,43)$. It has been suggested that the site that binds insulin could be at, or near, the IGF binding site (44) (Figure 1).

IGFBP7 possesses an IGF-independent activity (22). It shows strong homology with follistatin (also called activin-binding protein and encoded by the FST gene), although it lacks the Cterminus of follistatin (45). Like follistatin, IGFBP7 can bind to activin $\mathrm{A}$, and consequently influence the growth-suppressing effects of the TGF- $\beta$ superfamily. Expression of IGFBP7 has been shown to be upregulated in cells treated with TGF- $\beta 1$ and retinoic acid (RA) $(3,46)$. IGFBP7 also binds to heparan sulfate on the cell surface, but this interaction may be affected by cleavage of IGFBP7 by the trypsin-like integral-membrane serine peptidase matriptase (47). Matriptase, which cleaves substrates with Arg or Lys at the P1 position, has been incriminated in invasion and metastasis of breast cancer (48-51). The action of proteolytic cleavage, specifically located at the N-terminus, including the heparin-binding motif, decreases heparin-binding and the occupancy of IGF-1R $(48,52,53)$.

Furthermore, IGFBP7 was also discovered to bind to type IV collagen, initially by observing co-localization in the vascular basement membrane, and subsequently by direct measurement 
of attachment of radiolabeled IGFBP7 to extracellular matrix proteins (54). These authors also observed that IGFBP7 stimulated adhesion of human umbilical vein endothelial cells to type IV collagen substrate inducing morphological changes. St. Croix et al. (55) also found that IGFBP7 has a role in binding with type IV collagen. They showed that the IGFBP7 expression in tumor-associated endothelium is much higher than in healthy endothelial cells. IGFBP7 may also be a potential tumor endothelial cell marker, as identified by serial analysis of gene expression (SAGE). In this study, IGFBP7 and type IV collagen are co-expressed and interact with each other (55).

IGFBP7 mRNA is expressed in an extensive variety of human tissues, including liver, pancreas, small intestine, large intestine (gastrointestinal tract), as well as extra-gastrointestinal organs (brain, heart, spleen, kidney, placenta, lung, skeletal muscle, thymus, prostate, testis, ovary) as detected by northern blot hybridization (56). The mRNA expression of IGFBP7 and, of course, its translation is regulated by IGF-I, TGF$\beta$, and RA in epithelial cells of the prostatic gland (57). The immunohistochemical investigations performed on human prostatic tissues (normal) shows ubiquitous intense staining. Strong staining was also observed in the cilium of the respiratory system, epididymis, and fallopian tube. Most endothelial cells are positive, while fat cells, lymphocytes, and plasma cells are negative. IGFBP7 expression was restricted to specific cell types in the adrenal gland, kidney, and skeletal muscle, intimating a possible specialized role in these organs (56). IGFBP7 was also measurable in most human body fluids such as a serum, urine, and cerebrospinal fluid as well as amniotic fluid of pregnant individuals (58).

In contrast to IGFBP3 and IGFBP5, IGFBP7 is not influenced by glycosylation or phosphorylation. Proteolytic processing can modulate the protein expression level of IGFBP7. IGFBP7 is differentiated from other IGFBPs through regulatory mechanisms at the RNA and DNA levels (3).

IGFBP 7 is not only detectable in several healthy human tissues and human biological fluids, but also a variety of diverse cancers. However, importantly, accumulating studies clarified that IGFBP7 is up-regulated in some types of malignancies and down-regulated in others (Table 1). These entirely different manifestations suggest that IGFBP7 functions may be a "doubleedged sword" in cancer cell proliferation, progression, and prognosis, displaying an ambiguous action as an oncogene or suppressor gene in distinct types of cancers. The potential mechanisms and pathways associated with IGFBP7 and cancer are summarized in Figure 1. Our group has studied this aspect for Sirt1 $(59,79)$. Moreover, IGFBP7 can change cell sensitivity to chemotherapeutic drugs $(60,80)$, which suggests a potential beneficial value in anticancer treatment. In Table 1, the relationship between IGFBP7 and several of the most common cancers is highlighted.

\section{IGFBP7 WITH EPITHELIAL TUMORS}

We will now give an outline of studies of IGFBP7 and their importance in malignant neoplasms, such as epithelial tumors and mesenchymal tumors.
TABLE 1 | IGFBP7 expression in various tumors.

\begin{tabular}{|c|c|c|c|}
\hline Cancer type & $\begin{array}{l}\text { Expression } \\
\text { status }\end{array}$ & Test methods & References \\
\hline \multirow[t]{2}{*}{ Breast } & Down-regulation & qRT-PCR & $(57,59)$ \\
\hline & Down-regulation & $\mathrm{IHC}$ & $(57,58)$ \\
\hline \multirow[t]{2}{*}{ Gastric } & Up-regulation & IHC, qRT-PCR & $(60,61)$ \\
\hline & Down-regulation & IHC, qRT-PCR & (62) \\
\hline \multirow[t]{2}{*}{ Prostate } & Down-regulation & Northern blot, ISH & $(48,63)$ \\
\hline & Up-regulation & $\mathrm{IHC}$ & (20) \\
\hline Hepatocellular & Down-regulation & IHC, qRT-PCR & (64) \\
\hline \multirow[t]{2}{*}{ Colorectal } & Up-regulation & $\begin{array}{l}\text { IHC, Northern blot, } \\
\text { ELISA }\end{array}$ & $(65-69)$ \\
\hline & Down-regulation & $\mathrm{IHC}$ & $(70)$ \\
\hline Lung & Down-regulation & $\begin{array}{l}\text { IHC, qRT-PCR, } \\
\text { Northern blot }\end{array}$ & $(52,71,72)$ \\
\hline Esophageal & Up-regulation & $\mathrm{IHC}$ & $(73,74)$ \\
\hline Melanoma & Down-regulation & $\mathrm{IHC}$ & (75) \\
\hline \multirow[t]{2}{*}{ Glioma } & Down-regulation & qRT-PCR & $(76,77)$ \\
\hline & Up-reguation & $\begin{array}{l}\text { qRT-PCR, } \\
\text { Western blot }\end{array}$ & (78) \\
\hline
\end{tabular}

IHC, immunohistochemistry; ISH, in situ hybridization; qRT-PCR, quantitative reverse transcriptase-polymerase chain reaction; ELISA, enzyme-linked immunosorbent assay.

\section{Breast Cancer}

In the normal breast, IGFBP7 is identified in the epithelial layer of the breast ducts and lobules (56). Swisshelm et al. (46) found that the IGFBP7 gene is overexpressed in human mammary epithelial cells in senescence. The same authors report that IGFBP7 is overexpressed in normal, growing mammary epithelial cells exposed to all-trans-RA or fenretinide, a synthetic retinoid. However, immunohistochemical studies have indicated that mammary carcinoma epithelium does not show, or only lightly shows, IGFBP7 staining. Intense staining of IGFBP7 is found in normal and benign breast tissues but at low or untraceable levels in non-invasive breast cancers (DCIS). It is lost in all the invasive malignancies investigated. IGFBP7 expression is correlated with breast cancer progression $(61,81,82)$. Burger et al. (61) reported that IGFBP7 is expressed at much lower levels in metastatic neoplasms than in matched primary tumors, which was associated with a loss of heterozygosity $(\mathrm{LOH})$ in $50 \%$ of the cases. These authors also found that serial transplantation of xenografted human primary tumors reduces the levels of IGFBP7 mRNA at each transfer. Using qRT-PCR, Subramanian et al. (82) found that the expression of IGFBP7 mRNA in patient groups with TNM1 and TNM2 breast cancer was much higher than the poorer prognosis TNM3 group. The IGFBP7 level is also associated with the differentiation and prognosis of patients. Low IGFBP7 rate had a significantly reduced survival, poor differentiation, and a higher tumor stage; in all examined breast cancer cases, 15\% lacked IGFBP7 staining entirely, but $20 \%$ had weak staining, 32\% intermediate and 33\%, finally, showed strong staining (83). Over-expression of IGFBP7 in MDA-MB-468, a triple-negative breast cancer (TNBC) cell line, reduced cell division and migration through a specific inhibition of phosphorylation of MAPK (extracellular) signal-regulated 
kinase (ERK)-1/2 (81). The ability to reduce tumor growth also occurs in vivo. MDA-MB-231 is also a TNBC cell line. Utilizing this cell line and its more aggressive derivative cell line, 1833, Benatar et al. showed that treatment of TNBC cells with IGFBP7 causes cell cycle arrest and reduced cell growth, followed by induction of apoptosis or senescence, depending on the length of IGFBP7 exposure and dose (62). The xenografted tumor also shows decreased angiogenesis following tail-vein injection of recombinant IGFBP7, as demonstrated by significantly reduced CD34 and, most importantly, vascular endothelial growth factor (VEGF) expression. Zuo et al. (84) found that IGFBP7 inhibits MCF-7 cell proliferation and induces cellular senescence as a result of enhanced expression of p21 through a p53-independent pathway. p21Cip1, also known as cyclin-dependent kinase inhibitor 1 or CDK-interacting protein 1, is a cyclin-dependent kinase inhibitor that is able to inhibit all cyclin/CDK complexes The MCF-7 cells were arrested in G1 phase of the cell cycle. This setting adds to data generated by Wilson et al. (71) that indicated that IGFBP7 might act as a tumor suppressor by triggering senescence in breast cancer.

\section{Gastric Cancer}

Some initial experiments have implied that IGFBP7 is upregulated in gastric cancer patients matched to paired normal tissue based on immunohistochemistry and, quantitatively, on real-time polymerase chain reaction (qRTPCR) $(65,66,72,85,86)$. Takeno et al. (72) used a large-scale gene expression profiling and network analysis to identify genes accountable for tumorigenesis and tumor progression in patients affected with gastric cancer. These authors observed significant upregulation of IGFBP7 in undifferentiated cancers matched to the differentiated ones, indicating that IGFBP7 may participate as a critical functional component in gastric cancer differentiation. A constructive theory was identified originating from a correlation between the IGFBP7 expression and the depth of tumor invasion, the presence and the number of metastatic lymph nodes, distant metastasis/recurrence, or pathological stage in the stomach cancer individuals (85). In marked contrast to these reports, the low expression of IGFBP7 was also found to be associated with tumor progression and patients' poor survival in carcinoma of the stomach (67). Liu et al. suggest that the conflicting results may be caused by the differences in the tumor sites that were assessed in these studies. The contradictory data may be resolved by considering the non-homogeneous expression of IGFBP7 (68) and that IGFBP7 signaling in stromal fibroblasts might override its tumor-suppressor role in epithelial cells.

\section{Lung Tumors}

Healthy lung tissues show high IGFBP7 expression, which was investigated at the protein and mRNA levels. IGFBP7 was particularly evident in the small airway bronchial epithelial cells and the cytoplasm of lung bronchial epithelial cells, despite low expression of IGFBP7 in primary lung cancer tissues (69). Okamura et al. found that IGFBP7 expression was reduced in human primary and metastatic pulmonary carcinoma compared with healthy lung tissues (80). Expression of the IGFBP7 gene did not diverge significantly between tumors of different types, different stages (including tumor size and lymph node status), and grading $(69,87)$. DNA hypermethylation resulted in lower IGFBP7 expression for both lung cancer cell lines and primary lung tumors (87). The same report also indicated that most of the lung cancer cell lines showed down-regulation of IGFBP7 compared to normal tissues, and there was no difference in the expression pattern of IGFBP7 between small cell lung cancer (SCLC) cell lines and non-small cell lung cancer cell lines (NSCLC) (87). The qRT-PCR and immunohistochemistry results were congruent with the data from northern blot and western blot analysis (69). IGFBP7-positive transfectants of the H2170 cell line displayed remarkably decreased colony-forming ability in soft agar (in vitro cellular transformation technique), suppression of tumor growth rate in nude mice (genetic mutation harboring strain with deteriorated or absent thymus and subsequent inhibited immune system), and increased cellular apoptosis (programmed cell death), as well as activated caspase-3 expression level (69). A high serum level of IGFBP7 correlated with positive nodal status and could be a valuable biomarker to identify patients with poor outcomes in NSCLC. Another report suggested that downregulation of IGFBP7 rendered lung cancer cells resistant to cisplatin and altered the sensitivity to cisplatin-based anticancer therapy (80). A similar study reported that methylation and transcriptional silencing of specific genes are associated with the increase of cisplatin resistance (88). Also, Creighton et al. (89) showed that IGFBP7 was up-regulated in tumor xenografts created by the implantation of human lung adenocarcinoma (A549) cells in experimental animals.

\section{Colorectal Cancer}

Initial studies have suggested that IGFBP7 expression is drastically up-regulated in colorectal cancer (CRC) tissues compared with their paired non-cancerous tissues (70, 90). Follow-up studies reported similar data (91-93). Shao et al. observed that the upregulation of IGFBP7 is universal in colorectal cancer, especially in subjects affected with type II diabetes mellitus (DM). Ruan et al. $(63,93,94)$ indicated that IGFBP7 is robustly expressed in colorectal carcinoma of lowgrade type while it is weakly expressed in the high-grade type of colorectal carcinoma. However, this study's conclusion is in conflict with the finding of Adachi et al. who discovered IGFBP7 expression was correlated with a reduced overall outcome (90). IGFBP7 expression was mostly increased in CRC patients with Dukes' stages B and C compared to Dukes' stage A. Their findings suggest that plasma IGFBP7 levels do not reflect the local level of IGFBP7 in neoplastic tissue, and there is a significant difference regarding stage (of the neoplastic disease) and IGFBP7 expression. Thus, the expression of IGFBP7 may reflect disease progression. Also, a gradient of IGFBP7 immunohistochemistry staining is found along the axis of the crypt in human normal colonic epithelium, with much higher IGFBP7 expression in the differentiated epithelial cells at the surface compared to the lower expression at the crypt base (63). During Caco2 cell differentiation induced by sodium butyrate, IGFBP7 expression increased, and the expression showed a significant relationship with alkaline phosphatase (AKP) activity. 
These findings suggested that IGFBP7 is a potential pivotal molecule for colon cancer differentiation. Two studies indicated that IGFBP7 has a unique function in inhibiting epithelialmesenchymal transition (EMT) and metastasis via a TGF$\beta /$ Smad-dependent pathway $(63,95)$. However, down-regulation of IGFBP7 expression was found in colorectal tissues from a cohort of the Caucasian population (96). This conclusion is contradictory to some other reports, and the difference may be related to ethnic differences. Lin et al. have reported that IGFBP7 expression is negatively correlated with its methylation status in CRC (97). The hypermethylation state of the CpG islands of IGFBP7 is responsible for its down-regulation. They also described that DNA methylation is one of the mechanisms that regulates the expression of IGFBP7. The expression of IGFBP7 is at a low level or lost in CRC cell lines $(64,98)$. In an in vitro study, transfecting exogenous IGFBP7 cDNA into CRC cells induced cell growth inhibition, cell cycle arrest, a decrease in soft agar colony formation, and programmed cell death (93). Sato et al. have shown that overexpression of IGFBP7 in neoplastic CRC cells with an epithelial phenotype such as DLD-1 reduces anchorage-independent colony formation and xenograft tumor growth (64). IGFBP7 expression in tumor-associated fibroblasts can also stimulate colony formation when neoplastic epithelial cells are co-cultured with IGFBP7-expressing cancerassociated fibroblasts by secondary (paracrine) tumor-stroma interactions (68). In addition to its potential function as a tumor suppressor, Georges et al. demonstrated that IGFBP7 might have supplementary properties, which become obvious only in the broad framework of cancer progression, staging advancement, and metastasis formation (99). Recently, Li et al. (100) compared the expression of IGFBP7 in primary CRC with that in matched tissues arising from the liver metastases. They also investigated mechanistic aspects of IGFBP7 by examining the consequences of IGFBP7 knockdown and overexpression on the expression of EMT-associated proteins, such as E-cadherin, N-cadherin, and vimentin protein. These authors found that IGFBP7 is significantly downregulated in liver metastasis of patients with CRC. Also, the authors found that IGFBP7 overexpression influences the expression of EMT-associated genes, such as Ecadherin, thereby regulating the metastatic behavior of CRC cells. This data is paramount, highlighting the biological and clinical significance of IGFBP7 in CRC, although the role of IGFBP7 in CRC-associated liver metastasis requires further investigation. These intriguing findings support the conclusion put forward by Georges' et al. that "IGFBP3 and 7 cannot be simply assigned to the group of tumor suppressors, but have additional properties, which become evident only in the context of cancer progression and metastasis formation" (99).

\section{Prostate Cancer}

Several previous studies have detailed that IGFBP7 gene expression is significantly diminished in prostate carcinoma based on RT-PCR, northern blot, and in situ hybridization (ISH) $(57,101)$. Hwa et al. observed a progressive decrease of detectable IGFBP7 expression going from healthy cells of the glandular epithelium of the prostate to malignant prostate epithelial cells (57). This study also described that protein and
mRNA expression of IGFBP7 is regulated by IGF-I, TGF- $\beta$, and RA in prostatic epithelial cells. Mutaguchi et al. revealed that inactivation of IGFBP7 occurs through $\mathrm{CpG}$ methylation, and the tumor-suppressive activity of IGFBP7 relies on the induction of programmed cell death in an IGF-I independent manner in cancer of the prostatic gland (101). Moreover, Tennant et al. generated similar data confirming that IGFBP7 is detectable in the normal prostatic epithelium but progressively decreases when the prostatic epithelium degenerates toward malignancy (73). However, these findings have been challenged by Degeorges et al. who reported that prostatic intraepithelial neoplasia (PIN), prostatic adenocarcinoma, and prostatic cancer metastases express IGFBP7 with no differential based on stage or grade.

In contrast, secretory epithelium of the normal prostatic gland and benign prostatic hyperplasia do not usually express this molecule (102). Discordant results in prostatic gland research are unfortunately not uncommon, and even the classification of prostatic neoplasia has been changed several times in the last two decades. Moreover, non-neoplastic conditions that mimic prostate cancer have been better identified only in the previous decade. The observed differences in IGFBP7 expression might be caused by the different sources of prostatic epithelial cells. It seems incontrovertible that aberrant IGFBP7 promoter hypermethylation and simultaneous IGFBP7 gene silencing occurs in prostatic cancer cell lines, and the rate of IGFBP7 hypermethylation is significantly higher in cancer of the prostatic gland $(60 \%)$ and high grade prostatic intraepithelial neoplasia (40\%) than that in benign prostatic hyperplasia (15\%) and histologically benign prostatic epithelium adjacent to the tumor (0\%) (103). The results also suggest that the CpG methylation of IGFBP7 may be a unique biomarker of prostate cancer and pre-invasive neoplasms. Both IGFBP7 mRNA and protein expression are drastically increased during senescence of the normal epithelium of the prostatic gland (74), which supports the role of IGFBP7 as a tumor suppressor. The re-expression of IGFBP7 in a human prostate cancer cell line M12 led to a lengthening of cell doubling time, a decline in colony formation in soft agar, significant alteration in epithelial morphology, enhanced propensity to undergo apoptosis, and, finally, a reduction in the number and size of tumor formation in vivo (104). Another study suggested that over-expression of IGFBP7 in M12 cells alters cell cycle kinetics by delaying the cells in the G1 phase of the cell cycle (103). They also reported that IGFBP7 expression in the M12 cell line results in expanded sensitivity to programmed cell death in agreement with the earlier study (104). Tennant et al. showed a significant inverse relationship between IGFBP7 expression levels and proliferation in the LuCaP 23.12 prostate tumor xenografts (73). The above findings suggest that IGFBP7 plays a pivotal role in prostate cancer tumor suppression and senescence.

\section{Hepatocellular Cancer}

The principal source of IGFBPs is the liver, and IGFBP7 mRNA is expressed in healthy human liver (76). IGFBP7 gene expression is clearly significantly down-regulated in human HCC tumor samples and HCC cell lines compared 
with healthy hepatocytes. It is inversely correlated with the clinical stages and histopathological grades of HCC (77). In each stage, IGFBP7 expression was remarkably much lower in the poorly differentiated type of HCC compared with moderately differentiated HCC. Expression of IGFBP7 is considerably downregulated by elevated astrocyte gene-1 (AEG-1), a novel oncogene that is overexpressed in $90 \%$ of the patients affected with HCC (73). This discovery suggests that IGFBP7 downregulation may be needed to mediate the tumor-promoting function of $A E G-1$. Chen et al. (77) have found that stable overexpression of IGFBP7 in HepG3 cells that artificially overexpressed AEG-1 led to a marked decrease in proliferation and colony formation, and induced senescence. They also found that there is a full deletion of the IGFBP7 gene in some patients. Inhibition of angiogenesis, as evidenced by a decline in CD31 staining, was shown to be a major factor in the marked inhibition of tumor growth resulting from IGFBP7 overexpression in the HepG3-AEG1 model system. Downregulation of IGFBP7 expression was connected with hypermethylation of the $\mathrm{CpG}$ islands in the IGFBP7 promoter in murine SV40T/t antigen-induced hepatocarcinogenesis and human HBV-related HCC (78, 105). Li et al. found that the frequency of serum IGFBP7 promoter methylation is significantly higher in HCC patients than the controls (105). This study also indicated that serum IGFBP7 methylation is as sensitive as alpha-fetoprotein (AFP), a common malignancy biomarker extremely useful in the diagnosis of HCC.

Moreover, employing a combination of IGFBP7 gene promoter methylation and AFP level can improve the sensitivity of AFP in the diagnosis of HCC. New research indicates that IGFBP7 can suppress not only cancer cells but also modulate the tumor microenvironment, and this double effect may have a lasting impact on inhibiting both primary tumors and distant metastasis (42). Xenografts without IGFBP7 display increased spontaneous tumorigenesis without affecting healthy development, increased proliferation, reduced senescence, and activation of the IGF1 signaling pathway. Conversely, the overexpression of IGFBP7 decreases tumor growth by activating an antitumor immune response (2). Forced overexpression of IGFBP7 in an AEG-1-overexpressing HCC cell model caused an inhibition of in vitro growth and, simultaneously, induced senescence, and extremely suppressed in vivo growth in nude mice that revealed inhibition of angiogenesis (77).

\section{Esophageal Cancer}

Kashyap et al. have produced several reports regarding IGFBP7 expression in esophageal carcinomas, including Barrett carcinoma, esophageal adenocarcinoma (EAC), and squamous cell carcinoma of the esophagus (ESCC) (106-108). These studies have shown up-regulation and more than 4-fold over-expression of IGFBP7 in Barrett metaplasia and EAC as related to healthy tissues. Also, they examined IGFBP7 expression in normal tissues and ESCC-derived tissue sections using immunohistochemistry. They found that more than $90 \%$ of ESCC cases were openly positive with identification in both the cytoplasm and nucleus in most of the histological tissue sections (106).
Furthermore, there is a significant increase in IGFBP7 expression in EAC compared to healthy tissues (109), although these authors reported that there was a broad range of expression from low to high. Kim et al. have found consistent results showing that the expression of IGFBP7 was significantly increased in neoplasms with stage 3 compared with stage 0 neoplasms (75). DNA methylation of the IGFBP7 promoter resulted in an association with transcriptional silencing in esophageal adenocarcinoma and Barrett carcinoma cell lines. Definitely, it was a common feature in Barrett and EAC tissues and correlated with the silencing of protein expression. The low IGFBP7 expression was discovered to be related to a more prolonged survival of patients harboring an EAC (74).

\section{IGFBP7 WITH MESENCHYMAL TUMORS}

\section{Glioma}

Tian et al. found that IGFBP7 mRNA levels were substantially decreased in human glioma in comparison to healthy brain tissue (110) and that low levels of IGFBP7 mRNA were associated with larger tumor size, and patients with higher IGFBP7 expression had longer overall survival. Pen et al. (111) described that IGFBP7 acts as a tumor suppressor by lowering glioblastoma cell growth and inducing senescence, although not programmed cell death (111). Contrary to these findings, Jiang et al. found that IGFBP7 was highly overexpressed in glioma tissues compared to healthy brain tissues using RT-PCR and western blot. Furthermore, IGFBP7 expression correlated well with tumor grade and low overall glioma patient survival (112). This group also found that IGFBP7 mediates glioma cell growth and cell migration through the regulation of AKT and ERK1/2 activation (112). Other reports claimed that IGFBP7 was also robustly expressed in glioblastoma blood vessels and could induce the formation of "capillary-like tubes" by endothelial cells of the brain (113-116). These findings indicate that IGFBP7 stimulates glioma cell progression, and this aspect correlates with vessel formation. There are multiple grades of glioma with grade IV being the most malignant. Glioblastoma multiforme (GBM), which corresponds to grade $\mathrm{IV}$, is the most aggressive and very infiltrative, and several mechanisms have been suggested for why the marked formation of blood vessels observed in this kind of glioma is associated with poor survival.

\section{Melanoma}

A major study found that IGFBP7 gene expression is missing in primary melanomas bearing an activating mutation of the $B$-Raf gene $(B R A F)$ but apparently not in primary melanomas with wild-type BRAF (117). Its silencing is due to promoter hypermethylation. Also, the expression of IGFBP7 in melanoma cells containing the BRAF mutation can induce cell senescence and apoptosis. Reinstatement of IGFBP7 function utilizing the addition of recombinant IGFBP7 (rIGFBP7) causes programmed cell death in BRAF-positive cell lines derived from human melanoma, and systemically administered rIGFBP7 also has the capacity to suppress the growth of BRAF-positive tumors in xenograft mouse models (118). The pronounced reduction 
of IGFBP7 expression in metastatic samples indicates that during the development of melanoma, there is a substantial selection against IGFBP7 expression. This finding suggests that IGFBP7 acts as a melanoma tumor suppressor gene, which can inhibit BRAF-MEK-ERK signaling. It can efficiently induce programmed cell death in BRAF-positive melanoma cell lines (118). However, Scurr et al. concluded that BRAF mutational status has no relationship with the loss of IGFBP7 in melanoma (119). Employing intratumoral injection of a plasmid carrying IGFBP7 cDNA, Chen et al. found that melanoma growth in mice could be inhibited, due to the induction of apoptosis and the reduction in vascular endothelial growth factor (VEGF) expression (120). This new finding implies that IGFBP7 may have a potential therapeutic role in curing melanoma.

\section{IGFBP3 - IGFBP7 CROSSTALK}

The IGFBPs are a family of homologous proteins as indicated early in this review. They have co-developed with the IGFs (121). IGFBP3 and IGFBP7 are the unique members of the IGFBP superfamily that regulate the bioavailability of insulin and IGFs and have a similar structure and functions. IGFBP3 has a very high affinity for IGFs. In fact, it can transport $>75 \%$ of serum IGF-I and -II, while its affinity for insulin is very low. Conversely, IGFBP7 attaches to insulin with a very high affinity (500-fold more elevated compared to other IGFBPs) but has a low affinity for IGF-I and -II protein (22). In the last few years, there has been an increasing number of studies and findings regarding the roles and mechanisms of IGFBP3 and IGFBP7, and their relationships with many kinds of diseases, especially in different cancer types. Some of these studies pay attention to the impact of IGFBP3/IGFBP7 interaction. Here we have reviewed the potential relationship of these two proteins (Figure 2) and their critical role in several kinds of common cancers and the development of treatments for cancers.

Several reports have described that the binding proteins have the ability to inhibit cell proliferation and increase apoptosis in neoplastic cells $(2,4,20,122)$. IGFBP3 has been proven to inhibit cell proliferation in breast, lung, colon, prostate, and bone tumor cells and some cell lines to reduce tumor cell growth $(2,3,22$, $27,28)$. Coherent with these data, p53, and growth inhibitory agents, including RA, TGF- $\beta$, and anti-estrogens, can give rise to increased expression of IGFBP3 $(20,123)$. IGFBP7 can regulate the growth-suppressing effects of the TGF- $\beta$ superfamily, and similarly the expression of IGFBP7 can be upregulated by cellular treatment with TGF- $\beta 1$ and RA $(46,57,74)$. IGFBP7 also plays a role as a tumor suppressor in the liver, urinary bladder, cervix uteri, lung, esophagus, thyroid, as well as head and neck cancer $(42,45,46,57,74)$. It is a potentially pivotal molecule whose expression correlates with cancer differentiation $(72,95)$. Also, the expression of IGFBP3 and IGFBP7 is frequently reduced in several kinds of cancers, and this decrease is usually caused by promoter methylation $(98,124)$. The promoter of IGFBP3 is hypermethylated in neoplasms of kidney, ovary, liver, stomach, large intestine, breast, and mesothelium (124-127). Another report described that DNA methylation and transcriptional silencing of specific genes are correlated with the expression of IGFBP7 in breast, lung, liver, prostate, esophageal, CRC cell lines $(46,64,74,78,89,98,105,109)$. Li et al. reported that the serum level of IGFBP7 methylation is as sensitive as AFP in the diagnosis of HCC (105). Treatment with 5-aza-dC decreased expression of IGFBP3 in HCC cell lines (127) and IGFBP7 in CRC cell lines (97). Expression profiling identified three pathways altered in cellular immortalization of the p53 mutated skin fibroblast cell lines, MDAH041 and MDAH087: interferon, cell cycle, and cytoskeleton (128). Expression of IGFBP3 or IGFBP7 in these cells inhibited colony formation at low cell density. This finding is consistent with Wilson et al. who found that over-expression of IGFBP7 in MCF7 breast cancer cells inhibits cell proliferation and induces cellular senescence (71). Georges et al. also described that the silencing of IGFBP3 and IGFBP7 in CRC cell lines lowered cell proliferation, colony formation, and, in the case of IGFBP3, also reduced cell migration (99). Increasing levels of IGFBP3 and IGFBP7 can reduce the levels of free IGFs, which in turn results in decreased binding of IGF to IGF-IR and IGF-IIR, leading to inhibition of cell growth and proliferation and potential activation of apoptosis (128). Moreover, the IGFBP3 and IGFBP7 genes are tightly regulated by their microenvironment. It seems that the stable expression of IGFBP3 and IGFBP7 is critical for many cellular functions because the regulation of these genes has been associated with malignant properties (78, 129, 130). The current data are probably limited, but it should be emphasized that additional properties of these two molecules in the context of cancer progression and metastasis will become evident in the next few years (116). The major attributes of IGFBPs that could enhance their abilities to regulate IGF actions at cytologic and extracellular levels include ternary complex formation, nuclear localization and transactivation, spatio-temporal expression pattern, and interaction with the cell surface and extracellular proteins (131). Recently, tumor microenvironment in cancer formation has been an object of intense investigation. Considering the vast field, we may mention some of the most recent proteo-transcriptomics data with a focus on ovarian cancer. A key feature of this disease is its unique microenvironment involving tumor cell spheroids (TU), tumorassociated T cells (TAT), and tumor-associated-macrophages (TAM) that promote cancer progression, chemoresistance, and immunosuppression. Recently, Worzfeld et al. presented data accrued from global, cell type-specific, parallel proteomic and transcriptomic analyses of tumor cell spheroids, TAT and TAM in the peritoneal microenvironment of high grade serous ovarian adenocarcinoma (HGSOC) (132). These authors identified several intercellular signaling pathways responsible for driving cancer cell adhesion, invasion and metastasis and immunosurveillance, all of which seem to be strongly associated with patient survival. CD163 $3^{\text {low }}$ cells produce signaling molecules associated with favorable clinical outcome due to recruitment and activation of T cells (CXCL9-11, IL-15) and up-regulation of interferon signaling in TAM. Conversely, CD163 high cells secrete proteins promoting cancer cell stemness and angiogenesis. Both TAM and TU also release factors such as ECM remodeling 


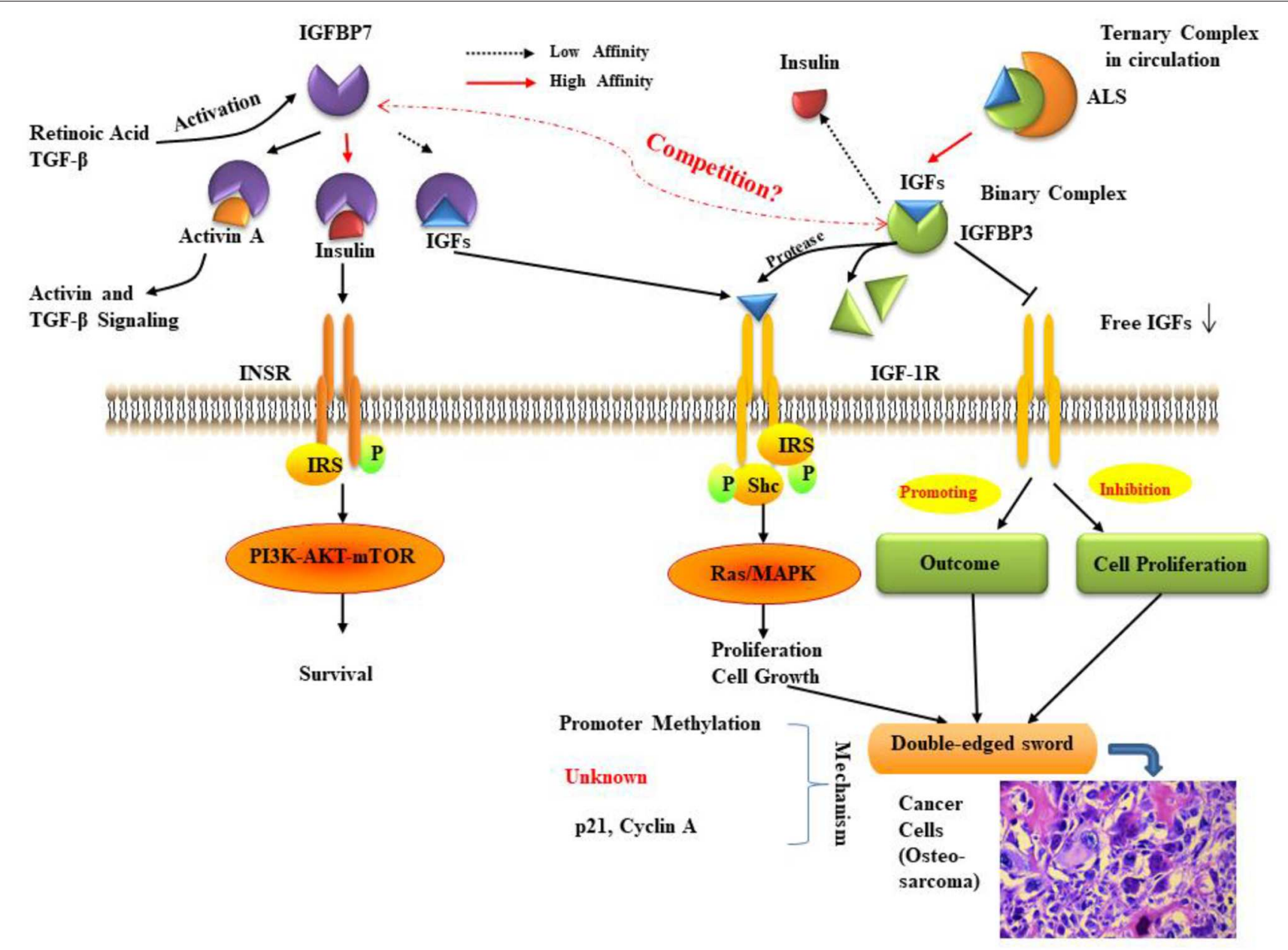

FIGURE 2 | The relationship between IGFBP3 and IGFBP7. IGF bioavailability is determined by sequestration in (ternary) complexes with IGFBP3 and ALS in the circulation, or in (binary) complexes with IGFBP3 in the cell environment. IGFBP7 binding partners are insulin, IGF-I, and activin, the levels of which can be controlled by retinoic acid and TGF- $\beta$. The function of IGFBP7 and IGFBP3 may be a double-edged sword in cancer proliferation, prognosis, and survival. The molecular mechanisms for IGFBP7 and IGFBP3 suppression of cancer remain to be fully elucidated, but some studies indicate that the primary mechanisms involve promoter methylation and the regulation of p21. ALS: Acid labile subunit; IGF: insulin-like growth factor; IGFBP7: IGF binding protein 7; IGF-1R: IGF-1 receptor; INSR: insulin receptor; IRS: insulin receptor substrate; MAPK: mitogen-activated protein kinase; mTOR: mammalian target of rapamycin; Shc: Src homology 2 domain-containing; TGF: transforming growth factor. As cancer cells are shown (histological inset), osteosarcoma cells show anaplastic cytological features associated with osteoid formation.

proteins that reprogram immune cells to be immunosuppressed, and, therefore potentially, pro-tumorigenic (132).

\section{DISCUSSION}

Over the last decades, many laboratories have confirmed that IGFs play an essential and pivotal role in cell growth, differentiation, and metabolic processes within the human body $(1,2)$. It seems clear that IGFBP7 and IGFBP3 are unique and critical members of the IGF signaling axis. IGFBP3 is the most abundant circulating IGFBP and a major IGF carrier protein $(3,23)$, while IGFBP7 is a high-affinity insulin-binding protein. In different types of cancers, IGFBP7 plays an inhibitory role by curbing proliferation and inducing apoptosis and senescence. However, there are also several conflicting findings and different conclusions, which clearly demonstrate that IGFBP7 is a key player responsible for tumorigenesis and tumor progression in patients affected by gastric cancer (72). These entirely different opinions suggest that IGFBP7 functions may be a "double-edged sword" in cancer proliferation, progression, and prognosis. IGFBP3 can function as a tumor suppressor and is downregulated in some neoplastic tissues, but it nevertheless shows overexpression in association with markers of poor outcome in some tumor types (133-135). Especially in breast cancer, the opposite result is seen in some studies $(133,134)$. IGFBP3, therefore, appears to elicit a 2-fold response in tumors. This conclusion also pertains to the expression of IGFBP7 in prostate and colorectal cancer $(57,90,96,102)$. The expression of IGFBP3 and IGFBP7 is often reduced in several kinds of cancers. This decline is usually caused by promoter methylation transcriptional silencing of specific genes $(46,124)$. The reasons 
for the observed increases in IGFBP3 and IGFBP7 expression remain unclear at present. The contradictory data suggest that IGFBP3 and IGFBP7 might be antiapoptotic or proapoptotic, depending on the cellular environments. Shao et al. have reported relatively high expression of IGFBP7 in most colorectal cancer patients with type II diabetes mellitus (DM) (91). Furthermore, the expression level appeared to be significantly related to the level of fasting glucose in these patients. Also, IGFBP7 is found to be increased in type $2 \mathrm{DM}$ patients receiving no pharmacological therapy (136). Although there is limited understanding of the detailed molecular mechanisms so far, there are several papers that have provided evidence for mechanisms for IGFBP7 involvement in suppression of cancer, one of which is the critical mechanism of inactivation of IGFBP7 expression by aberrant hypermethylation (93); a second mechanism has been proposed to be via regulation of $\mathrm{p} 21$ and cyclin A/CDK-2 activity and resulting induction of apoptosis (137). The upregulation of IGFBP7 may be triggered by alterations in the gene structure or abnormalities of upstream regulatory mechanisms (91). The serum level of IGFBP7 methylation is as sensitive as AFP in the diagnosis of HCC (105). This finding indicates that IGFBP7 may be a potential diagnostic biomarker in cancers. Further investigations are required to identify the complex biological role and detail molecular mechanisms of each IGFBP in different cancer types and their relationship with insulin and plasma glucose to elucidate the relationship between cancers and type II DM $(29,59,138,139)$. In consideration of the obesity and diabetes pandemics, the re-expression of these genes and genes associated with growth factors in complex signaling pathways may boost a rational strategy for blocking cancer formation at an early stage.

\section{REFERENCES}

1. Vincent AM, Feldman EL. Control of cell survival by IGF signaling pathways. Growth Horm IGF Res. (2002) 12:193-7. doi: 10.1016/S1096-6374(02)00017-5

2. LeRoith D, Roberts CT Jr. The insulin-like growth factor system and cancer. Cancer Lett. (2003) 195:127-37. doi: 10.1016/S0304-3835(03)00159-9

3. Burger AM, Leyland-Jones B, Banerjee K, Spyropoulos DD, Seth AK. Essential roles of IGFBP-3 and IGFBP-rP1 in breast cancer. Eur J Cancer. (2005) 41:1515-27. doi: 10.1016/j.ejca.2005.04.023

4. Rajah R, Katz L, Nunn S, Solberg P, Beers T, Cohen P. Insulinlike growth factor binding protein (IGFBP) proteases: functional regulators of cell growth. Prog Growth Factor Res. (1995) 6:273-84. doi: 10.1016/0955-2235(95)00012-7

5. Pollak M. The insulin and insulin-like growth factor receptor family in neoplasia: an update. Nat Rev Cancer. (2012) 12:159-69. doi: $10.1038 / \mathrm{nrc} 3215$

6. Steiner DF, Chan SJ, Welsh JM, Kwok SC. Structure and evolution of the insulin gene. Annu Rev Genet. (1985) 19:463-84. doi: 10.1146/annurev.ge.19.120185.002335

7. Li H, Batth IS, Qu X, Xu L, Song N, Wang R, et al. IGF-IR signaling in epithelial to mesenchymal transition and targeting IGF-IR therapy: overview and new insights. Mol Cancer. (2017) 16:6. doi: 10.1186/s12943-0160576-5

8. Xu L, Zhou R, Yuan L, Wang S, Li X, Ma H, et al. IGF1/IGF1R/STAT3 signaling-inducible IFITM2 promotes gastric cancer growth and metastasis. Cancer Lett. (2017) 393:76-85. doi: 10.1016/j.canlet.2017.02.014

\section{AUTHOR CONTRIBUTIONS}

LJ and CS revised the topic in the literature systematically. LJ wrote the first draft of the manuscript. FS revised the statistics of several studies. CS secured funding. MW revised critically the draft. LJ, FS, MW, and CS reviewed and approved the final version of the manuscript.

\section{ACKNOWLEDGMENTS}

This research has been supported by the 2019 Shiyan Taihe Hospital Foundation Program (2019 JJXM020) to LJ and by a grant to CS from the Stollery Children's Hospital Foundation and supporters of the Lois Hole Hospital for Women through the Women and Children's Health Research Institute (WCHRI). Moreover, CS has been supported by the Hubei Province Natural Science Funding for Hubei University of Technology (100Talent Grant for Recruitment Program of Foreign Experts Total Funding: Digital PCR and NGS-based diagnosis for infection and oncology, 2017-2022), Österreichische Krebshilfe Tyrol (Krebsgesellschaft Tirol, Austrian Tyrolean Cancer Research Institute, 2008), Austrian Research Fund (Fonds zur Förderung der wissenschaftlichen Forschung), Canadian Foundation for Women's Health, Cancer Research Society, Canadian Institutes of Health Research, and the Saudi Cultural Bureau, Ottawa, Canada. The funders had no role in study design, data collection, and analysis, decision to publish, or preparation of the manuscript. Finally, we are incredibly grateful for the guidance and support of LJ by her chair, Dr. Jicai Zhang (Shiyan Taihe Hospital, College of Biomedical Engineering, Hubei University of Medicine, Shiyan, China).

9. Afratis NA, Bouris P, Skandalis SS, Multhaupt HA, Couchman JR, Theocharis $\mathrm{AD}$, et al. IGF-IR cooperates with ERalpha to inhibit breast cancer cell aggressiveness by regulating the expression and localisation of ECM molecules. Sci Rep. (2017) 7:40138. doi: 10.1038/ srep40138

10. Bailey KL, Agarwal E, Chowdhury S, Luo J, Brattain MG, Black JD, et al. TGFbeta/Smad3 regulates proliferation and apoptosis through IRS1 inhibition in colon cancer cells. PLOS ONE. (2017) 12:e0176096. doi: 10.1371/journal.pone.0176096

11. Casa AJ, Dearth RK, Litzenburger BC, Lee AV, Cui X. The type I insulin-like growth factor receptor pathway: a key player in cancer therapeutic resistance. Front Biosci. (2008) 13:3273-87. doi: 10.2741/2925

12. Malaguarnera R, Belfiore A. The emerging role of insulin and insulin-like growth factor signaling in cancer stem cells. Front Endocrinol. (2014) 5:10. doi: $10.3389 /$ fendo.2014.00010

13. Yu H, Mistry J, Nicar MJ, Khosravi MJ, Diamandis A, van Doorn J, et al. Insulin-like growth factors (IGF-I, free IGF-I and IGF-II) and insulin-like growth factor binding proteins (IGFBP-2, IGFBP-3, IGFBP-6, and ALS) in blood circulation. J Clin Lab Anal. (1999) 13:166-72. doi: 10.1002/ (SICI)1098-2825(1999)13:4<166::AID-JCLA5>3.0.CO;2-X

14. Fowlkes JL, Thrailkill KM, George-Nascimento C, Rosenberg CK, Serra DM. Heparin-binding, highly basic regions within the thyroglobulin type-1 repeat of insulin-like growth factor (IGF)-binding proteins (IGFBPs) $-3,-5$, and-6 inhibit IGFBP-4 degradation. Endocrinology. (1997) 138:2280-5. doi: 10.1210/endo.138.6.5182

15. Miyamoto S, Yano K, Sugimoto S, Ishii G, Hasebe T, Endoh Y, et al. Matrix metalloproteinase-7 facilitates insulin-like growth factor bioavailability 
through its proteinase activity on insulin-like growth factor binding protein 3. Cancer Res. (2004) 64:66-71. doi: 10.1158/0008-5472.CAN-03-1916

16. Manes S, Llorente M, Lacalle RA, Gomez-Mouton C, Kremer L, Mira E, et al. The matrix metalloproteinase-9 regulates the insulin-like growth factortriggered autocrine response in DU-145 carcinoma cells. J Biol Chem. (1999) 274:6935-45. doi: 10.1074/jbc.274.11.6935

17. Forbes BE, McCarthy P, Norton RS. Insulin-like growth factor binding proteins: a structural perspective. Front Endocrinol. (2012) 3:38. doi: $10.3389 /$ fendo. 2012.00038

18. Grimberg A, Cohen P. Role of insulin-like growth factors and their binding proteins in growth control and carcinogenesis. J Cell Physiol. (2000) 183:1-9. doi: 10.1002/(SICI) 1097-4652(200004)183:1<1::AID-JCP1>3.0.CO;2-J

19. Hu Q, Zhou Y, Ying K, Ruan W. IGFBP, a novel target of lung cancer? Clin Chim Acta. (2017) 466:172-7. doi: 10.1016/j.cca.2017.01.017

20. Firth SM, Baxter RC. Cellular actions of the insulin-like growth factor binding proteins. Endocr Rev. (2002) 23:824-54. doi: 10.1210/er.2001-0033

21. Subramanian A, Sharma A, Mokbel K. Insulin-like growth factor binding proteins and breast cancer. Breast Cancer Res Treat. (2008) 107:181-94. doi: 10.1007/s10549-007-9549-0

22. Hwa $\mathrm{V}, \mathrm{Oh} \mathrm{Y}$, Rosenfeld RG. The insulin-like growth factor-binding protein (IGFBP) superfamily. Endocr Rev. (1999) 20:761-87. doi: 10.1210/er.20.6.761

23. Marzec KA, Baxter RC, Martin JL. Targeting insulin-like growth factor binding protein-3 signaling in triple-negative breast cancer. Biomed Res Int. (2015) 2015:638526. doi: 10.1155/2015/638526

24. Baxter RC, Meka S, Firth SM. Molecular distribution of IGF binding protein-5 in human serum. J Clin Endocrinol Metab. (2002) 87:271-6. doi: $10.1210 /$ jcem.87.1.8151

25. Beattie J, Phillips K, Shand JH, Szymanowska M, Flint DJ, Allan GJ. Molecular interactions in the insulin-like growth factor (IGF) axis: a surface plasmon resonance (SPR) based biosensor study. Mol Cell Biochem. (2008) 307:221-36. doi: 10.1007/s11010-007-9601-8

26. Clemmons DR, Busby WH, Arai T, Nam TJ, Clarke JB, Jones JI, et al. Role of insulin-like growth factor binding proteins in the control of IGF actions. Prog Growth Factor Res. (1995) 6:357-66. doi: 10.1016/0955-2235(95)00013-5

27. Ressler S, Radhi J, Aigner T, Loo C, Zwerschke W, Sergi C. Insulin-like growth factor-binding protein- 3 in osteosarcomas and normal bone tissues. Anticancer Res. (2009) 29:2579-87.

28. Santer FR, Bacher N, Moser B, Morandell D, Ressler S, Firth SM, et al. Nuclear insulin-like growth factor binding protein-3 induces apoptosis and is targeted to ubiquitin/proteasome-dependent proteolysis. Cancer Res. (2006) 66:3024-33. doi: 10.1158/0008-5472.CAN-05-2013

29. Osasan S, Zhang M, Shen F, Paul PJ, Persad S, Sergi C. Osteogenic sarcoma: a 21st century review. Anticancer Res. (2016) 36:4391-8. doi: 10.21873/anticanres. 10982

30. Guix M, Faber AC, Wang SE, Olivares MG, Song $\mathrm{Y}$, Qu S, et al. Acquired resistance to EGFR tyrosine kinase inhibitors in cancer cells is mediated by loss of IGF-binding proteins. J Clin Invest. (2008) 118:2609-19. doi: $10.1172 / \mathrm{JCI} 34588$

31. Liu B, Lee HY, Weinzimer SA, Powell DR, Clifford JL, Kurie JM, et al. Direct functional interactions between insulin-like growth factor-binding protein-3 and retinoid $\mathrm{X}$ receptor-alpha regulate transcriptional signaling and apoptosis. J Biol Chem. (2000) 275:33607-13. doi: 10.1074/jbc.M002 547200

32. Schedlich LJ, O'Han MK, Leong GM, Baxter RC. Insulinlike growth factor binding protein-3 prevents retinoid receptor heterodimerization: implications for retinoic acid-sensitivity in human breast cancer cells. Biochem Biophys Res Commun. (2004) 314:83-8. doi: $10.1016 / j . b b r c .2003 .12 .049$

33. Ikezoe T, Tanosaki S, Krug U, Liu B, Cohen P, Taguchi H, et al. Insulin-like growth factor binding protein-3 antagonizes the effects of retinoids in myeloid leukemia cells. Blood. (2004) 104:237-42. doi: 10.1182/blood-2003-07-2203

34. Fanayan S, Firth SM, Baxter RC. Signaling through the Smad pathway by insulin-like growth factor-binding protein-3 in breast cancer cells. Relationship to transforming growth factor-beta 1 signaling. J Biol Chem. (2002) 277:7255-61. doi: 10.1074/jbc.M108038200

35. Fanayan S, Firth SM, Butt AJ, Baxter RC. Growth inhibition by insulinlike growth factor-binding protein-3 in T47D breast cancer cells requires transforming growth factor-beta (TGF-beta) and the type II TGF-beta receptor. J Biol Chem. (2000) 275:39146-51. doi: 10.1074/jbc.M006964200

36. Butt AJ, Firth SM, King MA, Baxter RC. Insulin-like growth factor-binding protein-3 modulates expression of $\mathrm{Bax}$ and $\mathrm{Bcl}-2$ and potentiates p53independent radiation-induced apoptosis in human breast cancer cells. J Biol Chem. (2000) 275:39174-81. doi: 10.1074/jbc.M908888199

37. Watanabe J, Takiyama Y, Honjyo J, Makino Y, Fujita Y, Tateno M, et al. Role of IGFBP7 in diabetic nephropathy: TGF-beta1 induces IGFBP7 via smad2/4 in human renal proximal tubular epithelial cells. PLoS ONE. (2016) 11:e0150897. doi: 10.1371/journal.pone.0150897

38. Sadowski T, Dietrich S, Koschinsky F, Sedlacek R. Matrix metalloproteinase 19 regulates insulin-like growth factor-mediated proliferation, migration, and adhesion in human keratinocytes through proteolysis of insulinlike growth factor binding protein-3. Mol Biol Cell. (2003) 14:4569-80. doi: 10.1091/mbc.e03-01-0009

39. Shibata Y, Tsukazaki T, Hirata K, Xin C, Yamaguchi A. Role of a new member of IGFBP superfamily, IGFBP-rP10, in proliferation and differentiation of osteoblastic cells. Biochem Biophys Res Commun. (2004) 325:1194-200. doi: 10.1016/j.bbrc.2004.10.157

40. Yamanaka Y, Wilson EM, Rosenfeld RG, Oh Y. Inhibition of insulin receptor activation by insulin-like growth factor binding proteins. J Biol Chem. (1997) 272:30729-34. doi: 10.1074/jbc.272.49.30729

41. Oh Y, Nagalla SR, Yamanaka Y, Kim HS, Wilson E, Rosenfeld RG. Synthesis and characterization of insulin-like growth factor-binding protein (IGFBP)7. Recombinant human mac25 protein specifically binds IGF-I -II. J Biol Chem. (1996) 271:30322-5. doi: 10.1074/jbc.271.48.30322

42. Akiel M, Guo C, Li X, Rajasekaran D, Mendoza RG, Robertson CL, et al. IGFBP7 deletion promotes hepatocellular Carcinoma. Cancer Res. (2017) 77:4014-25. doi: 10.1158/0008-5472.CAN-1 6-2885

43. Bartram I, Erben U, Ortiz-Tanchez J, Blunert K, Schlee C, Neumann $\mathrm{M}$, et al. Inhibition of IGF1-R overcomes IGFBP7-induced chemotherapy resistance in T-ALL. BMC Cancer. (2015) 15:663. doi: 10.1186/s12885-015$1677-z$

44. de Meyts P, Sajid W, Palsgaard J, Theede A-M, Gauguin L, Aladdin H, et al. Insulin and IGF-I receptor structure and binding mechanism. In: Saltiel AR, Pessin JE, editors. Madame Curie Bioscience Database [Internet]. Austin, TX: Landes Bioscience (2000-2013). Available online at: https://www.ncbi.nlm. nih.gov/books/NBK6192/

45. Kato MV. A secreted tumor-suppressor, mac25, with activin-binding activity. Mol Med. (2000) 6:126-35. doi: 10.1007/BF03401780

46. Swisshelm K, Ryan K, Tsuchiya K, Sager R. Enhanced expression of an insulin growth factor-like binding protein (mac25) in senescent human mammary epithelial cells and induced expression with retinoic acid. Proc Natl Acad Sci USA. (1995) 92:4472-6. doi: 10.1073/pnas.92.10.4472

47. Chen YB, Liao XY, Zhang JB, Wang F, Qin HD, Zhang L, et al. ADAR2 functions as a tumor suppressor via editing IGFBP7 in esophageal squamous cell carcinoma. Int J Oncol. (2017) 50:622-30. doi: 10.3892/ijo.201 6.3823

48. Ahmed S, Jin X, Yagi M, Yasuda C, Sato Y, Higashi S, et al. Identification of membrane-bound serine proteinase matriptase as processing enzyme of insulin-like growth factor binding protein-related protein1 (IGFBP-rP1/angiomodulin/mac25). FEBS J. (2006) 273:615-27. doi: 10.1111/j.1742-4658.2005.05094.x

49. Damalanka VC, Han Z, Karmakar P, O’Donoghue AJ, La Greca F, Kim T, et al. Discovery of selective matriptase and hepsin serine protease inhibitors: useful chemical tools for cancer cell biology. J Med Chem. (2019) 62:480-90. doi: 10.1021 /acs.jmedchem. 8 b01536

50. Rather GM, Lin SY, Lin H, Banach-Petrosky W, Hirshfield KM, Lin $\mathrm{CY}$, et al. Activated matriptase as a target to treat breast cancer with a drug conjugate. Oncotarget. (2018) 9:25983-92. doi: 10.18632/oncotarget. 25414

51. Zoratti GL, Tanabe LM, Hyland TE, Duhaime MJ, Colombo E, Leduc R, et al. Matriptase regulates c-Met mediated proliferation and invasion in inflammatory breast cancer. Oncotarget. (2016) 7:58162-73. doi: 10.18632 /oncotarget.11262

52. Sato J, Hasegawa S, Akaogi K, Yasumitsu H, Yamada S, Sugahara K, et al. Identification of cell-binding site of angiomodulin (AGM/TAF/Mac25) 
that interacts with heparan sulfates on cell surface. J Cell Biochem. (1999) 75:187-95.

53. Evdokimova V, Tognon CE, Benatar T, Yang W, Krutikov K, Pollak M, et al. IGFBP7 binds to the IGF-1 receptor and blocks its activation by insulin-like growth factors. Sci Signal. (2012) 5:ra92. doi: 10.1126/scisignal.2003184

54. Akaogi K, Okabe Y, Sato J, Nagashima Y, Yasumitsu H, Sugahara $\mathrm{K}$, et al. Specific accumulation of tumor-derived adhesion factor in tumor blood vessels and in capillary tube-like structures of cultured vascular endothelial cells. Proc Natl Acad Sci USA. (1996) 93:8384-9. doi: 10.1073 /pnas.93.16.8384

55. St Croix B, Rago C, Velculescu V, Traverso G, Romans KE, Montgomery E, et al. Genes expressed in human tumor endothelium. Science. (2000) 289:1197-202. doi: 10.1126/science.289.5482.1197

56. Degeorges A, Wang F, Frierson HF Jr, Seth A, Sikes RA. Distribution of IGFBP-rP1 in normal human tissues. J Histochem Cytochem. (2000) 48:74754. doi: $10.1177 / 002215540004800603$

57. Hwa V, Tomasini-Sprenger C, Bermejo AL, Rosenfeld RG, Plymate SR. Characterization of insulin-like growth factor-binding protein-related protein-1 in prostate cells. J Clin Endocrinol Metab. (1998) 83:4355-62. doi: 10.1210/jcem.83.12.5341

58. Lopez-Bermejo A, Khosravi J, Corless CL, Krishna RG, Diamandi A, Bodani U, et al. Generation of anti-insulin-like growth factor-binding protein-related protein 1 (IGFBP-rP1/MAC25) monoclonal antibodies and immunoassay: quantification of IGFBP-rP1 in human serum and distribution in human fluids and tissues. J Clin Endocrinol Metab. (2003) 88:3401-8. doi: 10.1210/jc.2002-021315

59. Sergi C, Shen F, Liu S. Insulin/IGF-1R, SIRT1, and FOXOs Pathways - an intriguing interaction platform for bone and osteosarcoma. Front Endocrinol. (2019) 10:93. doi: 10.3389/fendo.2019.00093

60. Tomimaru Y, Eguchi H, Wada H, Noda T, Murakami M, Kobayashi S, et al. Insulin-like growth factor-binding protein 7 alters the sensitivity to interferon-based anticancer therapy in hepatocellular carcinoma cells. $\mathrm{Br} \mathrm{J}$ Cancer. (2010) 102:1483-90. doi: 10.1038/sj.bjc.6605669

61. Burger AM, Zhang X, Li H, Ostrowski JL, Beatty B, Venanzoni M, et al. Down-regulation of T1A12/mac25, a novel insulin-like growth factor binding protein related gene, is associated with disease progression in breast carcinomas. Oncogene. (1998) 16:2459-67. doi: 10.1038/sj.onc.1201772

62. Benatar T, Yang W, Amemiya Y, Evdokimova V, Kahn H, Holloway C, et al. IGFBP7 reduces breast tumor growth by induction of senescence and apoptosis pathways. Breast Cancer Res Treat. (2012) 133:563-73. doi: 10.1007/s10549-011-1816-4

63. Ruan W, Zhu S, Wang H, Xu F, Deng H, Ma Y, et al. IGFBP-rP1, a potential molecule associated with colon cancer differentiation. Mol Cancer. (2010) 9:281. doi: 10.1186/1476-4598-9-281

64. Sato Y, Chen Z, Miyazaki K. Strong suppression of tumor growth by insulin-like growth factor-binding protein-related protein $1 /$ tumorderived cell adhesion factor/mac25. Cancer Sci. (2007) 98:1055-63. doi: $10.1111 / j .1349-7006.2007 .00502 . x$

65. Boussioutas A, Li H, Liu J, Waring P, Lade S, Holloway AJ, et al. Distinctive patterns of gene expression in premalignant gastric mucosa and gastric cancer. Cancer Res. (2003) 63:2569-77.

66. Kim B, Bang S, Lee S, Kim S, Jung Y, Lee C, et al. Expression profiling and subtype-specific expression of stomach cancer. Cancer Res. (2003) 63:8248-55.

67. Liu L, Yang Z, Zhang W, Yan B, Gu Q, Jiao J, et al. Decreased expression of IGFBP7 was a poor prognosis predictor for gastric cancer patients. Tumour Biol. (2014) 35:8875-81. doi: 10.1007/s13277-014-2160-1

68. Rupp C, Scherzer M, Rudisch A, Unger C, Haslinger C, Schweifer N, et al. IGFBP7, a novel tumor stroma marker, with growth-promoting effects in colon cancer through a paracrine tumor-stroma interaction. Oncogene. (2015) 34:815-25. doi: 10.1038/onc.2014.18

69. Chen Y, Pacyna-Gengelbach M, Ye F, Knosel T, Lund P, Deutschmann N, et al. Insulin-like growth factor binding protein-related protein 1 (IGFBPrP1) has potential tumour-suppressive activity in human lung cancer. $J$ Pathol. (2007) 211:431-8. doi: 10.1002/path.2132

70. Malarstig A, Wagsater D, Lofgren S, Hugander A, Zar N, Dimberg J. Tumour-derived adhesion factor in colorectal cancer. Mol Med Rep. (2009) 2:971-6. doi: 10.3892/mmr_00000200
71. Wilson HM, Birnbaum RS, Poot M, Quinn LS, Swisshelm K. Insulin-like growth factor binding protein-related protein 1 inhibits proliferation of MCF-7 breast cancer cells via a senescence-like mechanism. Cell Growth Differ. (2002) 13:205-13.

72. Takeno A, Takemasa I, Doki Y, Yamasaki M, Miyata H, Takiguchi S, et al. Integrative approach for differentially overexpressed genes in gastric cancer by combining large-scale gene expression profiling and network analysis. $\mathrm{Br}$ J Cancer. (2008) 99:1307-15. doi: 10.1038/sj.bjc.6604682

73. Tennant MK, Vessella RL, Sprenger CC, Sikes RA, Hwa V, Baker LD, et al. Insulin-like growth factor binding protein-related protein 1 (IGFBP$\mathrm{rP} 1 / \mathrm{mac} 25$ ) is reduced in human prostate cancer and is inversely related to tumor volume and proliferation index in Lucap 23.12 xenografts. Prostate. (2003) 56:115-22. doi: 10.1002/pros.10223

74. Lopez-Bermejo A, Buckway CK, Devi GR, Hwa V, Plymate SR, Oh Y, et al. Characterization of insulin-like growth factor-binding protein-related proteins (IGFBP-rPs) 1, 2, and 3 in human prostate epithelial cells: potential roles for IGFBP-rP1 and 2 in senescence of the prostatic epithelium. Endocrinology. (2000) 141:4072-80. doi: 10.1210/endo.141.11.7783

75. Kim SM, Park YY, Park ES, Cho JY, Izzo JG, Zhang D, et al. Prognostic biomarkers for esophageal adenocarcinoma identified by analysis of tumor transcriptome. PLoS ONE. (2010) 5:e15074. doi: 10.1371/journal.pone.0015074

76. Roddam AW, Allen NE, Appleby P, Key TJ, Ferrucci L, Carter HB, et al. Insulin-like growth factors, their binding proteins, and prostate cancer risk: analysis of individual patient data from 12 prospective studies. Ann Intern Med. (2008) 149:461-71. doi: 10.7326/0003-4819-149-7-200810070-00006

77. Chen D, Yoo BK, Santhekadur PK, Gredler R, Bhutia SK, Das SK, et al. Insulin-like growth factor-binding protein-7 functions as a potential tumor suppressor in hepatocellular carcinoma. Clin Cancer Res. (2011) 17:6693701. doi: 10.1158/1078-0432.CCR-10-2774

78. Komatsu S, Okazaki Y, Tateno M, Kawai J, Konno H, Kusakabe M, et al. Methylation and downregulated expression of mac25/insulin-like growth factor binding protein-7 is associated with liver tumorigenesis in SV40T/t antigen transgenic mice, screened by restriction landmark genomic scanning for methylation (RLGS-M). Biochem Biophys Res Commun. (2000) 267:10917. doi: 10.1006/bbrc.1999.1937

79. Al-Bahrani R, Tuertcher D, Zailaie S, Abuetabh Y, Nagamori S, Zetouni $\mathrm{N}$, et al. Differential SIRT1 expression in hepatocellular carcinomas and cholangiocarcinoma of the liver. Ann Clin Lab Sci. (2015) 45:3-9.

80. Okamura J, Huang Y, Moon D, Brait M, Chang X, Kim MS. Downregulation of insulin-like growth factor-binding protein 7 in cisplatin-resistant non-small cell lung cancer. Cancer Biol Ther. (2012) 13:148-55. doi: 10.4161/cbt.13.3.18695

81. Amemiya Y, Yang W, Benatar T, Nofech-Mozes S, Yee A, Kahn H, et al. Insulin like growth factor binding protein-7 reduces growth of human breast cancer cells and xenografted tumors. Breast Cancer Res Treat. (2011) 126:373-84. doi: 10.1007/s10549-010-0921-0

82. Subramanian A, Sharma AK, Banerjee D, Jiang WG, Mokbel $\mathrm{K}$. Evidence for a tumour suppressive function of IGF1-binding proteins in human breast cancer. Anticancer Res. (2007) 27:3513-8. doi: 10.1016/S1359-6349(07)71772-X

83. Landberg G, Ostlund H, Nielsen NH, Roos G, Emdin S, Burger AM, et al. Downregulation of the potential suppressor gene IGFBP-rP1 in human breast cancer is associated with inactivation of the retinoblastoma protein, cyclin E overexpression and increased proliferation in estrogen receptor negative tumors. Oncogene. (2001) 20:3497-505. doi: 10.1038/sj.onc.1204471

84. Zuo S, Liu C, Wang J, Wang F, Xu W, Cui S, et al. IGFBP-rP1 induces p21 expression through a p53-independent pathway, leading to cellular senescence of MCF-7 breast cancer cells. J Cancer Res Clin Oncol. (2012) 138:1045-55. doi: 10.1007/s00432-012-1153-y

85. Sato Y, Inokuchi M, Takagi Y, Otsuki S, Fujimori Y, Yanaka Y, et al. Relationship between expression of IGFBP7 and clinicopathological variables in gastric cancer. J Clin Pathol. (2015) 68:795-801. doi: 10.1136/jclinpath-2015-202987

86. Sill M, Schroder C, Shen Y, Marzoq A, Komel R, Hoheisel JD, et al. Protein profiling gastric cancer and neighboring control tissues using high-content antibody microarrays. Microarrays. (2016) 5:19. doi: $10.3390 /$ microarrays5030019 
87. Chen Y, Cui T, Knosel T, Yang L, Zoller K, Petersen I. IGFBP7 is a p53 target gene inactivated in human lung cancer by DNA hypermethylation. Lung Cancer. (2011) 73:38-44. doi: 10.1016/j.lungcan.2010.10.015

88. Chang X, Monitto CL, Demokan S, Kim MS, Chang SS, Zhong $\mathrm{X}$, et al. Identification of hypermethylated genes associated with cisplatin resistance in human cancers. Cancer Res. (2010) 70:2870-9. doi: 10.1158/0008-5472.CAN-09-3427

89. Creighton CJ, Bromberg-White JL, Misek DE, Monsma DJ, Brichory F, Kuick R, et al. Analysis of tumor-host interactions by gene expression profiling of lung adenocarcinoma xenografts identifies genes involved in tumor formation. Mol Cancer Res. (2005) 3:119-29. doi: 10.1158/1541-7786.MCR-04-0189

90. Adachi Y, Itoh F, Yamamoto H, Arimura Y, Kikkawa-Okabe Y, Miyazaki K, et al. Expression of angiomodulin (tumor-derived adhesion factor/mac25) in invading tumor cells correlates with poor prognosis in human colorectal cancer. Int J Cancer. (2001) 95:216-22. doi: 10.1002/10970215(20010720)95:4<216::aid-ijc1037>3.0.co;2-o

91. Shao L, Huang Q, Luo M, Lai M. Detection of the differentially expressed gene IGF-binding protein-related protein-1 and analysis of its relationship to fasting glucose in Chinese colorectal cancer patients. Endocr Relat Cancer. (2004) 11:141-8. doi: 10.1677/erc.0.0110141

92. Luo MJ, Lai MD. Identification of differentially expressed genes in normal mucosa, adenoma and adenocarcinoma of colon by SSH. World J Gastroenterol. (2001) 7:726-31. doi: 10.3748/wjg.7.726

93. Ruan W, Xu E, Xu F, Ma Y, Deng H, Huang Q, et al. IGFBP7 plays a potential tumor suppressor role in colorectal carcinogenesis. Cancer Biol Ther. (2007) 6:354-9. doi: 10.4161/cbt.6.3.3702

94. Ruan W, Wang Y, Ma Y, Xing X, Lin J, Cui J, et al. HSP60, a protein downregulated by IGFBP7 in colorectal carcinoma. J Exp Clin Cancer Res. (2010) 29:41. doi: 10.1186/1756-9966-29-41

95. Zhu S, Zhang J, Xu F, Xu E, Ruan W, Ma Y, et al. IGFBP-rP1 suppresses epithelial-mesenchymal transition and metastasis in colorectal cancer. Cell Death Dis. (2015) 6:e1695. doi: 10.1038/cddis.2015.59

96. Ye F, Chen Y, Knosel T, Schluns K, Pacyna-Gengelbach M, Deutschmann N, et al. Decreased expression of insulin-like growth factor binding protein 7 in human colorectal carcinoma is related to DNA methylation. J Cancer Res Clin Oncol. (2007) 133:305-14. doi: 10.1007/s00432-006-0171-z

97. Lin J, Zhu YM, Shao LN, Huang Q, Lai MD. [Hypomethylation of 5'CpG island of insulin-like growth factor binding protein-related protein 1 is associated with its overexpression in colorectal cancer]. Zhonghua Bing $\mathrm{Li}$ Xue Za Zhi. (2008) 37:512-6. doi: 10.3321/j.issn:0529-5807.2008.08.003

98. Lin J, Lai M, Huang Q, Ma Y, Cui J, Ruan W. Methylation patterns of IGFBP7 in colon cancer cell lines are associated with levels of gene expression. $J$ Pathol. (2007) 212:83-90. doi: 10.1002/path.2144

99. Georges RB, Adwan H, Hamdi H, Hielscher T, Linnemann U, Berger MR. The insulin-like growth factor binding proteins 3 and 7 are associated with colorectal cancer and liver metastasis. Cancer Biol Ther. (2011) 12:69-79. doi: 10.4161/cbt.12.1.15719

100. Li Y, Xi Y, Zhu G, Jia J, Huang H, Liu Y, et al. Downregulated IGFBP7 facilitates liver metastasis by modulating epithelialmesenchymal transition in colon cancer. Oncol Rep. (2019) 42:1935-45. doi: 10.3892/or.201 9.7303

101. Mutaguchi K, Yasumoto H, Mita K, Matsubara A, Shiina H, Igawa M, et al. Restoration of insulin-like growth factor binding protein-related protein 1 has a tumor-suppressive activity through induction of apoptosis in human prostate cancer. Cancer Res. (2003) 63:7717-23.

102. Degeorges A, Wang F, Frierson HF Jr, Seth A, Chung LWK, Sikes RA, et al. Human prostate cancer expresses the low affinity insulin-like growth factor binding protein IGFBP-rP1. Cancer Res. (1999) 59:2787-90.

103. Sullivan L, Murphy TM, Barrett C, Loftus B, Thornhill J, Lawler M, et al. IGFBP7 promoter methylation and gene expression analysis in prostate cancer. J Urol. (2012) 188:1354-60. doi: 10.1016/j.juro.2012. 06.002

104. Sprenger CC, Damon SE, Hwa V, Rosenfeld RG, Plymate SR. Insulin-like growth factor binding protein-related protein 1 (IGFBP-rP1) is a potential tumor suppressor protein for prostate cancer. Cancer Res. (1999) 59:2370-5.
105. Li F, Fan YC, Gao S, Sun FK, Yang Y, Wang K. Methylation of serum insulin-like growth factor-binding protein 7 promoter in hepatitis B virusassociated hepatocellular carcinoma. Genes Chromosomes Cancer. (2014) 53:90-7. doi: $10.1002 / \mathrm{gcc} .22120$

106. Kashyap MK, Pawar HA, Keerthikumar S, Sharma J, Goel R, Mahmood R, et al. Evaluation of protein expression pattern of stanniocalcin 2, insulinlike growth factor-binding protein 7, inhibin beta A and four and a half LIM domains 1 in esophageal squamous cell carcinoma. Cancer Biomark. (2012) 12:1-9. doi: 10.3233/CBM-120289

107. Kashyap MK, Harsha HC, Renuse S, Pawar H, Sahasrabuddhe NA, Kim MS, et al. SILAC-based quantitative proteomic approach to identify potential biomarkers from the esophageal squamous cell carcinoma secretome. Cancer Biol Ther. (2010) 10:796-810. doi: 10.4161/cbt.10.8.12914

108. Hao Y, Triadafilopoulos G, Sahbaie P, Young HS, Omary MB, Lowe AW. Gene expression profiling reveals stromal genes expressed in common between barrett's esophagus and adenocarcinoma. Gastroenterology. (2006) 131:925-33. doi: 10.1053/j.gastro.2006.04.026

109. Smith E, Ruszkiewicz AR, Jamieson GG, Drew PA. IGFBP7 is associated with poor prognosis in oesophageal adenocarcinoma and is regulated by promoter DNA methylation. Br J Cancer. (2014) 110:775-82. doi: 10.1038/bjc.2013.783

110. Tian X, Zhang L, Sun L, Xue Y, Xie S. Low expression of insulin-like growth factor binding protein 7 associated with poor prognosis in human glioma. $J$ Int Med Res. (2014) 42:651-8. doi: 10.1177/0300060513503926

111. Pen A, Durocher Y, Slinn J, Rukhlova M, Charlebois C, Stanimirovic DB, et al. Insulin-like growth factor binding protein 7 exhibits tumor suppressive and vessel stabilization properties in U87MG and T98G glioblastoma cell lines. Cancer Biol Ther. (2011) 12:634-46. doi: 10.4161/cbt.12.7.17171

112. Jiang W, Xiang C, Cazacu S, Brodie C, Mikkelsen T. Insulin-like growth factor binding protein 7 mediates glioma cell growth and migration. Neoplasia. (2008) 10:1335-42. doi: 10.1593/neo.08694

113. Tomanek B, Iqbal U, Blasiak B, Abulrob A, Albaghdadi H, Matyas JR, et al. Evaluation of brain tumor vessels specific contrast agents for glioblastoma imaging. Neuro Oncol. (2012) 14:53-63. doi: 10.1093/neuonc/nor 183

114. Iqbal U, Albaghdadi H, Luo Y, Arbabi M, Desvaux C, Veres T, et al. Molecular imaging of glioblastoma multiforme using anti-insulin-like growth factorbinding protein-7 single-domain antibodies. Br J Cancer. (2010) 103:160616. doi: $10.1038 /$ sj.bjc. 6605937

115. Pen A, Moreno MJ, Durocher Y, Deb-Rinker P, Stanimirovic DB. Glioblastoma-secreted factors induce IGFBP7 and angiogenesis by modulating Smad-2-dependent TGF-beta signaling. Oncogene. (2008) 27:6834-44. doi: 10.1038/onc.2008.287

116. Pen A, Moreno MJ, Martin J, Stanimirovic DB. Molecular markers of extracellular matrix remodeling in glioblastoma vessels: microarray study of laser-captured glioblastoma vessels. Glia. (2007) 55:559-72. doi: 10.1002/glia.20481

117. Wajapeyee N, Serra RW, Zhu X, Mahalingam M, Green MR. Oncogenic BRAF induces senescence and apoptosis through pathways mediated by the secreted protein IGFBP7. Cell. (2008) 132:363-74. doi: 10.1016/j.cell.2007.12.032

118. Wajapeyee N, Kapoor V, Mahalingam M, Green MR. Efficacy of IGFBP7 for treatment of metastatic melanoma and other cancers in mouse models and human cell lines. Mol Cancer Ther. (2009) 8:3009-14. doi: 10.1158/1535-7163.MCT-09-0470

119. Scurr LL, Pupo GM, Becker TM, Lai K, Schrama D, Haferkamp S, et al. IGFBP7 is not required for B-RAF-induced melanocyte senescence. Cell. (2010) 141:717-27. doi: 10.1016/j.cell.2010.04.021

120. Chen RY, Chen HX, Lin JX, She WB, Jiang P, Xu L, et al. In-vivo transfection of pcDNA3.1-IGFBP7 inhibits melanoma growth in mice through apoptosis induction and VEGF downexpression. J Exp Clin Cancer Res. (2010) 29:13. doi: 10.1186/1756-9966-29-13

121. Kelley KM, Oh Y, Gargosky SE, Gucev Z, Matsumoto T, Hwa V, et al. Insulin-like growth factor-binding proteins (IGFBPs) and their regulatory dynamics. Int J Biochem Cell Biol. (1996) 28:619-37. doi: 10.1016/1357-2725(96)00005-2

122. Wong RS. Apoptosis in cancer: from pathogenesis to treatment. J Exp Clin Cancer Res. (2011) 30:87. doi: 10.1186/1756-9966-30-87 
123. Yu H, Rohan T. Role of the insulin-like growth factor family in cancer development and progression. J Natl Cancer Inst. (2000) 92:1472-89. doi: $10.1093 /$ jnci/92.18.1472

124. Tomii K, Tsukuda K, Toyooka S, Dote H, Hanafusa T, Asano H, et al. Aberrant promoter methylation of insulin-like growth factor binding protein-3 gene in human cancers. Int J Cancer. (2007) 120:566-73. doi: $10.1002 /$ ijc. 22341

125. Ibanez de Caceres I, Dulaimi E, Hoffman AM, Al-Saleem T, Uzzo RG, Cairns P. Identification of novel target genes by an epigenetic reactivation screen of renal cancer. Cancer Res. (2006) 66:5021-8. doi: 10.1158/0008-5472.CAN-05-3365

126. Wiley A, Katsaros D, Chen H, Rigault de la Longrais IA, Beeghly A, Puopolo $\mathrm{M}$, et al. Aberrant promoter methylation of multiple genes in malignant ovarian tumors and in ovarian tumors with low malignant potential. Cancer. (2006) 107:299-308. doi: 10.1002/cncr.21992

127. Hanafusa T, Yumoto Y, Nouso K, Nakatsukasa H, Onishi T, Fujikawa T, et al. Reduced expression of insulin-like growth factor binding protein-3 and its promoter hypermethylation in human hepatocellular carcinoma. Cancer Lett. (2002) 176:149-58. doi: 10.1016/S0304-3835(01)00736-4

128. Fridman AL, Rosati R, Li Q, Tainsky MA. Epigenetic and functional analysis of IGFBP3 and IGFBPrP1 in cellular immortalization. Biochem Biophys Res Commun. (2007) 357:785-91. doi: 10.1016/j.bbrc.2007.04.019

129. Kansra S, Ewton DZ, Wang J, Friedman E. IGFBP-3 mediates TGF beta 1 proliferative response in colon cancer cells. Int J Cancer. (2000) 87:373-8. doi: 10.1002/1097-0215(20000801)87:3<373::aid-ijc10>3.0.co;2-x

130. Leibowitz BJ, Cohick WS. Endogenous IGFBP-3 is required for both growth factor-stimulated cell proliferation and cytokine-induced apoptosis in mammary epithelial cells. J Cell Physiol. (2009) 220:182-8. doi: $10.1002 /$ jcp. 21748

131. Allard JB, Duan C. IGF-binding proteins: why do they exist and why are there so many? Front Endocrinol. (2018) 9:117. doi: 10.3389/fendo.2018.00117

132. Worzfeld T, Finkernagel F, Reinartz S, Konzer A, Adhikary T, Nist A, et al. Proteotranscriptomics reveal signaling networks in the Ovarian cancer microenvironment. Mol Cell Proteomics. (2018) 17:270-89. doi: 10.1074/mcp.RA117.000400

133. Ren Z, Shin A, Cai Q, Shu XO, Gao YT, Zheng W. IGFBP3 mRNA expression in benign and malignant breast tumors. Breast Cancer Res. (2007) 9:R2. doi: $10.1186 /$ bcr 1634
134. Mu L, Katsaros D, Wiley A, Lu L, de la Longrais IA, Smith S, et al. Peptide concentrations and mRNA expression of IGF-I, IGF-II and IGFBP3 in breast cancer and their associations with disease characteristics. Breast Cancer Res Treat. (2009) 115:151-62. doi: 10.1007/s10549-0080046-x

135. Hansel DE, Rahman A, House M, Ashfaq R, Berg K, Yeo $\mathrm{CJ}$, et al. Met proto-oncogene and insulin-like growth factor binding protein 3 overexpression correlates with metastatic ability in well-differentiated pancreatic endocrine neoplasms. Clin Cancer Res. (2004) 10:6152-8. doi: 10.1158/1078-0432.CCR-0 4-0285

136. Lopez-Bermejo A. Insulin resistance after prenatal growth restriction: is it mediated by adiponectin deficiency? Clin Endocrinol. (2006) 64:479-80. doi: 10.1111/j.1365-2265.2006.02496.x

137. Sprenger CC, Vail ME, Evans K, Simurdak J, Plymate SR. Over-expression of insulin-like growth factor binding protein-related protein-1(IGFBP$\mathrm{rP} 1 / \mathrm{mac} 25)$ in the M12 prostate cancer cell line alters tumor growth by a delay in G1 and cyclin A associated apoptosis. Oncogene. (2002) 21:140-7. doi: 10.1038/sj.onc.1205021

138. Yang Y, Shen F, Huang W, Qin S, Huang JT, Sergi C, et al. Glucose is involved in the dynamic regulation of $\mathrm{m} 6 \mathrm{~A}$ in patients with Type 2 diabetes. J Clin Endocrinol Metab. (2019) 104:665-73. doi: 10.1210/jc.2018-00619

139. Zheng W, Shen F, Hu R, Roy B, Yang J, Wang Q, et al. Far upstream element-binding protein 1 binds the 3' untranslated region of PKD2 and suppresses its translation. J Am Soc Nephrol. (2016) 27:2645-57. doi: 10.1681/ASN.2015070836

Conflict of Interest: The authors declare that the research was conducted in the absence of any commercial or financial relationships that could be construed as a potential conflict of interest.

Copyright (c) 2020 Jin, Shen, Weinfeld and Sergi. This is an open-access article distributed under the terms of the Creative Commons Attribution License (CC BY). The use, distribution or reproduction in other forums is permitted, provided the original author(s) and the copyright owner(s) are credited and that the original publication in this journal is cited, in accordance with accepted academic practice. No use, distribution or reproduction is permitted which does not comply with these terms. 